\title{
The Impact of Foreign Direct Investment on Unemployment: Evidence from Arab countries
}

\author{
Ahmed Mohamed Ezzat \\ Vice Dean for Education - College of International Transport \\ and Logistics - Arab Academy for Science, Technology and \\ Maritime Transport (AAST) - Cairo branch- Egypt
}

\begin{abstract}
Theoretically, foreign direct investment (FDI) has the ability to solve a number of economic and social problems. Reducing unemployment is at the forefront of these problems. Empirical studies did not agree on the inevitability of the positive macroeconomic impact of FDI on reducing unemployment. In this paper, the macroeconomic impact of FDI on national unemployment rates in general and youth unemployment in particular is examined in 8 Arab countries. In estimating the model, a panel unit root, panel cointegration, and Granger causality tests are used. The positive impact of FDI on reducing national unemployment is proven in the group as a whole and individually in Jordan, Morocco, and Tunisia while it leads to increase unemployment in Egypt. The impact of FDI on reducing youth unemployment is not proven. The causal relationship in both directions between FDI and unemployment and the speed of adjustment towards the long-term equilibrium is not proven.
\end{abstract}

Key Words: Arab countries, DOLS and FMOLS, foreign direct investment, panel causality, panel cointegration, unemployment. 


\section{Introduction}

Unemployment, especially between youth, is considered of the most challenging macroeconomic problems in the Arab non-oil countries. Most of these countries suffer from low growth rates of employment opportunities when compared to population growth rates. Despite the rapid real economic growth rates in these countries during the last decade, they have not had a significant impact on unemployment rates. The challenges arising from unemployment increase if one takes into account the demographic distribution of the population in these countries. Early and prime working age population, from 15 to 54 , has a positive trend in the last decade and ranges between 56 percent and 69 percent of total population in these countries in 2018 (World Development Indicators of the World Bank(WDI 2019). However, the demographic dependency ratio ranges between 46 percent and 79 percent in 2018 (WDI 2019) referring to that these countries is far from entering the demographic opportunity. The unemployment rate among young people is twice the average of national unemployment rate in most of these countries. This is reflected on the dependency ratio younger dependents to the working-age population.

Many inappropriate public policies have exacerbated the unemployment crisis of past decades in these countries. These practices include misallocation of resources, inadequate investment targeting to labor-intensive sectors, lack of clear visibility and treatment of unemployment causes, insufficiency of competitive investment policies, large and inefficient bureaucracy, poor quality of education systems that led to increasing the gap between skills acquired from education and labor market requirements, and the deficiency of proper training even though the rapid development of technology globally. All of these represent a clear threat to political stability and security in these countries. Many observers consider unemployment and its consequences, especially among young 
people, to be the main cause of the uprisings in some of these countries. Recently, these countries adopt short and long run sustainable development plans considering unemployment reduction, especially among young people, as one of their main pillars.

Taking into account the inadequacy of domestic funding sources for sustainable development, these countries tend to attract foreign direct investment (FDI) to solve several economic, social, and political problems. Economically, FDI can help accelerate economic growth, improving labor market conditions, and enhancing productivity. Socially, FDI inflows support in enhancing the standard of living as it increases wages, improves the use of natural resources, and increases the need for improving education and health care. Politically, the FDI from Transnational Corporations often push government policies towards more competitive, transparent, and effective policy environment for investment in the area of regulations and taxation. Moreover, it improves the institutional and human capacities.

Economically, the literature focuses on the impact of FDI on inflation rate and unemployment rate as main variables used as proxies for macroeconomic stability (Strat et al. 2015). Communities are often more concerned with youth unemployment rates, with the recognition that it goes beyond just being an index of business cycles to become a structural issue threatening the future of nations that requires innovative solutions in which combined educational, financial, fiscal, social security, and labor policies. However, few of the literature focus on the impact of FDI on youth unemployment rate.

The traditional view confirms the importance of attracting FDI to enhance the demand for labor in the host country through accelerating economic growth. This affects not only labor in the sectors attracting FDI, but also it affects labor in the supportive domestic industries. However, many empirical studies have not 
been able to prove this relationship. Moreover, they state that dependence of foreign investment on domestic labor is minimal, especially on young people. The justification is a combination of factors, some of which are due to the host countries; while the other is to the foreign investor. Regarding host countries, the most important factor hindering the impact of foreign investment on domestic labor is that domestic workers in host countries are often unable to absorb the technology and production methods of the foreign investor. The most important factor related to the foreign investor is the reliance on capital and technology intensive production methods. Hence, although the gains from FDI have been verified theoretically, they have not been empirically confirmed, as these effects have been found to vary depending on the studied country or group of countries, the analyzed period, and the forms of investment.

In this paper, the goal is to develop a framework to analyze the macroeconomic impact of FDI on national unemployment as a whole in addition to youth unemployment in a number of Arab countries those suffer from relatively high unemployment and demographic dependency rates during the period 1991-2017 ${ }^{1}$. These countries are Algeria, Egypt, Jordan, Lebanon, Mauritania, Morocco, Sudan, and Tunisia. The specific objectives of this paper are to study the main characteristics of unemployment in the eight countries, examine the existence of the long-term effect of FDI on both of national and youth unemployment, examine the speed of adjustments in the short run in case of having the longterm effect of FDI on both of national and youth unemployment, estimate the impact of FDI on national and youth unemployment rates in the group of countries in addition to study the direction and significance of the impact for each of these countries individually, and draw policy conclusions. The main contribution of this paper is that it gives more attention to both of theoretical

${ }^{1}$ The relationship was only examined from the macro-economic point of view due to the lack of data for different industrial sectors in terms of employment and inflows of foreign direct investment by sectors. 
and empirical impact of FDI on youth unemployment rate that is relatively ignored especially in the Arab countries despite its importance in affecting the sustainability of economic development taking into account the stability of social and political dimensions.

The rest of the paper is organized as follows: the second section examines and analyzes the main characteristics of unemployment in the countries included in the study, the third section discusses theoretical background and relevant literature, the fourth section clarifies data sources, specification of the model, and estimation strategy, the fifth section introduces some empirical results, the last section includes a discussion of the results and policy implications.

\section{The main characteristics of unemployment in the eight countries}

As mentioned above, the study includes eight Arab countries, including four countries with an average unemployment rate, as a whole and in youth, that exceeds the same ratio in the average of the Middle East and North Africa. These countries are Egypt, Jordan, Sudan, and Tunisia. The other four countries, such as Mauritania, Algeria, Morocco, and Lebanon, have an unemployment rate that exceeds the same ratio as in the upper middle income countries.

Available statistics indicate that national unemployment rates declined significantly during the period 1991-2017 in a number of countries under study, notably Algeria, during 2000-2006, Morocco during 1995-2013, Tunisia during 1998-2007, Jordan during 2002-2010 and Lebanon during 2007-2016. The unemployment rate was slightly decreasing in both Mauritania and Sudan during the period. The unemployment rate in Egypt fluctuated between increasing and decreasing during the period. However, the remarkable jump in the rate of national 
unemployment in Egypt was during 2010, which contributed significantly to the Egyptian revolution in 2011 and it continued to rise until 2014, as shown in Figure (1).

Figure 1: The development of national unemployment rates

1991-2017

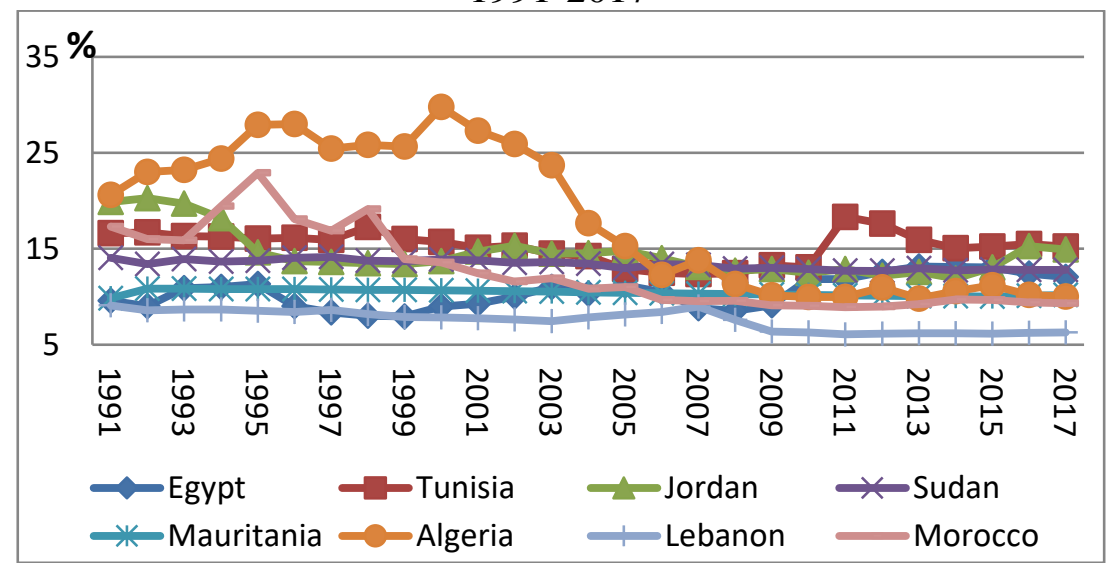

Source: World Development Indicators - the World Bank depending on ILO estimate.

The unemployment rate between youth is highly correlated to the national unemployment rate in all of the countries under the study with an exception of Mauritania. The correlation coefficient between both reach it's maximum in Algeria (98.7 percent) and its minimum in Tunisia (80.8 percent). In Mauritania, the correlation between national unemployment rates and the unemployment rate between youth was very weak, with a correlation coefficient of only 1.2 percent. This may be attributed to the fact that, despite the trend of the national unemployment rate to decline slightly during this period under study, as indicated above, because of the relatively small population, the unemployment rate among young people took an upward trend 
during this period. Figure (2) illustrates the development of youth unemployment rates during this period 1991-2017.

Figure 2: The development of youth unemployment rates 19912017

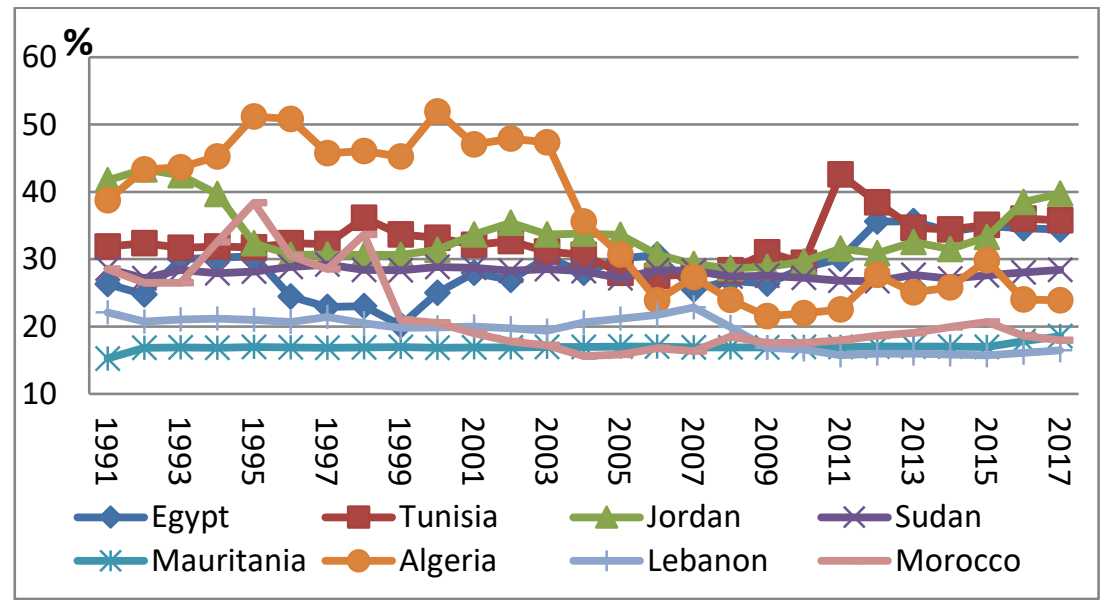

Source: World Development Indicators - the World Bank depending on ILO estimate.

A fundamental observation on the problem of unemployment in the countries under study is the inequitable distribution of employment opportunities between male and female. A review of the available data on unemployment rates by gender shows a focus on reducing unemployment among males only in all countries studied except Morocco. This leads to a significant inequality between male and female unemployment rates. The appendix shows the development of unemployment rates by gender in the countries studied over time.

These countries share a number of basic characteristics of unemployment. These common characteristics are:

a. Unemployment is one of the main significant macroeconomic problems in these countries, where the overall unemployment rates in these countries are relatively highly compared to other countries in the Arab countries. 
b. The rapid relatively real economic growth rate, especially during the last decade, has not had a significant impact on unemployment rates in these countries. This is despite the success of these countries in attracting relatively high rates of FDI when comparing the net inflows as a percentage of GDP in these countries with counterparts from low-income, middleincome countries, and the average Middle East and North African countries.

c. All of these countries suffer from low growth rates of employment opportunities when compared to population growth rates. With the inability to provide investment opportunities that provide more employment opportunities, especially among young people. One reason can be the concentration of foreign investment opportunities in sectors like oil and mining sectors which are non-labor intensive sectors. In addition to the relatively high share of Brownfield investments at the expense of Green field investments ${ }^{2}$. According to the World Investment Report of UNCTAD (UNCTAD 2019), the share of green field investments to the inflows of FDI in 2018 ranges from 5.5 percent in Lebanon and 28 percent in Morocco.

d. The unemployment rate among young people is twice the average of national unemployment rate in all countries except Morocco and Mauritania, where youth unemployment is less than twice the general average a bit.

e. The unemployment rate among women is higher than that of males, at over double the rate in some countries referring to the marginalization of women. This is with an exception of Morocco in which the rate of unemployment between males and females is approaching to a large extent.

\footnotetext{
2 The difference between Brown field and Green field investments lies on whether the foreign investment established new facilities or not. Brown field investment is a type of FDI that happens when a foreign investor purchases or leases an existing facility in the host country. The most common form of brown field investment is mergers and acquisitions. Green field investment is a type of FDI that happens when a foreign investor construct new facilities in the host country.
} 
f. Unemployment in all these countries represents a clear threat to political stability, security and the intensification of irregular migration flows.

g. Many inappropriate public policies have exacerbated the unemployment crisis of past decades in these countries. These practices include misallocation of resources, inadequate investment targeting to labor-intensive sectors, lack of clear visibility and treatment of unemployment causes, insufficiency of competitive investment policies, large and inefficient bureaucracy, poor quality of education systems that led to increasing the gap between skills acquired from education andlabor market requirements, and the deficiency of proper training even though the rapid development of technology globally.

h. These countries adopt sustainable development plans, both short and long run; one of their main pillars is to reduce unemployment, especially among young people. Most of these countries rely on FDI as a growth engine.

\section{Theoretical background and literature review}

This section reviews the conceptual review, the macroeconomic impact of FDI on unemployment rate theoretically, and the empirical studies of the effects of FDI trends on unemployment.

\subsection{Conceptual Review}

Here, we are concerned with the definition of the basic terms used, namely foreign direct investment (FDI) and unemployment.

FDI is defined as an investment involving a long-term relationship between an entity resident in a single economy and a project resident in another country. This long-term relationship reflects the constant interest and supervision of the foreign investor on the project (Adeyemi 2018). This investment can be either the purchase of a project in the target country or the expansion of an existing business in that country; this 
distinguishes FDI than portfolio investment where the latter means an investment in a group of various securities like stocks, hedge funds, and debentures for the purpose of achieving financial gain only without creating a permanent interest or effective administrative control over the institution (Haddad 2016).

Unemployment can be defined as the share of the labor force that is available for and actively looking for employment but not being currently employed (Mucuk and Demirsel 2013).The youth unemployment is the number of unemployed young people.

\subsection{Theoretical background}

The macroeconomic impact of FDI on unemployment rate has been extensively investigated within recent years in both developed and developing countries. Communities are often more concerned with youth unemployment rates because of their impact on young people themselves, businesses and communities. For young people themselves, they have less ability to spend as consumers and less ability to save and thus invest, leading to the inability to make fundamental changes in their lives and communities. The prevalence of youth unemployment also restricts the ability of companies to innovate and develop, which is an essential feature of youth employment. The effects on the young people themselves and companies are causing social unrest, rejecting the existing social and economic systems, and the threat of further dangers in the future. All of these affect their communities negatively currently and in the future (ManpowerGroup 2012).However, all economic theories and empirical studies have rarely investigated the impact of FDI on youth unemployment independently.

Theoretical models and empirical studies gave inconsistent results for the impact of FDI on unemployment rate depending on the nature of the countries, the periods, and the forms of investment. While some confirmed that negative effect of FDI on 
unemployment rate through affecting labor conditions, others stated that the negative effects are very limited and sometimes the effects are positive. Empirical studies on the impact of investment on youth unemployment have suffered from extreme scarcity. This section studies the relevant theories and literature explaining unemployment, how can FDI affect it, and empirical results of studies tested the macroeconomic impact of FDI on unemployment in developing countries.

In the classical and neo-classical economic theories, both of Pigou (1933) and Solow (1981) explained the equilibrium in the labor market as a result of the interactions between the demand for labor and its supply. The demand for labor is a derived demand as it is related to comparing marginal product of labor with real wages. The demand for labor curve is negatively related to real wage (Adeyemi 2018). The supply of labor is the decision of workers after comparing real wages with the opportunity cost of working. The supply of labor is positively related to real wages. If the equilibrium real wage rate is flexible to be determined in the market, the equilibrium can be reached at the full employment level of workers. Hence, unemployment, with an exceptional of frictional one, can result from the pressure of workers to raise real wages above its equilibrium level (Grahovac and Softić 2017). Accordingly, the channels of FDI to affect unemployment are real wages and physical productivity of labor.

Keynes opposed that unemployment would disappear in the short run if workers accepted lowering money wage rates because of rigorous and sticky wages which are confirmed during The Great Depression experiences ${ }^{3}$. Furthermore, he explained that the mechanism of automatic correction in the labor market will not work, especially at times of recession with excessive savings and weak private investment. Accordingly, Keynes stated that the

${ }^{3}$ The sticky wage theory states that wages always have a tendency to stability higher than its equilibrium level and the adjustment in case of unemployment is too slowly to keep the labor market always in equilibrium. 
level of employment at a particular period of time is a function of effective demand. The latter is determined by aggregate demand price and aggregate supply price ${ }^{4}$ (Keynes 1936). Accordingly, a decline in total effective demand leads to a gap between income and consumption. This gap need to be reduced by supporting investment opportunities, whether domestically or internationally, or it would cause unemployment to increase.

More recently, other theories have emerged in favor of the Keynesian interpretation of cyclical unemployment in times of recession because of the maintenance of higher wages. One of these theories is the insider-outsider theory ${ }^{5}$. According to this theory, insiders may put barriers to prevent their high wages and prevent themselves from the ability of employees to replace them with lower-priced outsiders. One of these barriers is presented in the implicit contract theory. According to the implicit contract theory, long-term labor contracts and labor laws limit the ability of employees to reduce wages in times of recession. Taking into account the ability of FDI to increase the demand for labor, outsiders may gain without losses to insiders. Arnott et al. (1987) stated that although the traditional implicit contract theory explained wage rigidities, it failed to explain unemployment. Alternatively, Arnott et al. (1987) explained the unemployment by a combination of concerted factors. Firstly, the reduction in the value of marginal product where the worker is currently employed which leads to a decrease in their wage. Secondly, not only wages but severance pay also affects workers' decisions. Thirdly, the cost and time spent in searching for an alternative job where the value of marginal product is higher. Consequently, unemployment may decrease because of attracting FDI in case of increasing the value of marginal product per worker and

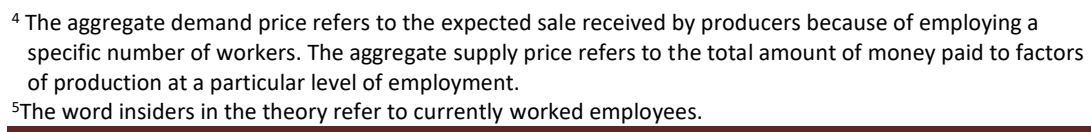


expanding labor market options through relying on export orientation of domestic firms even if insiders put barriers to prevent themselves.

Efficiency wage theory gave another explanation for sticky wage. The theory stated that employees find it better for them to pay employees higher than necessary wages. The higher wages can improve the employees' health, nourish, and other conditions of life that can enhance them improving productivity. Relying on this theory, FDI can put pressure to raise wages in order to improve the productivity and loyalty of skilled workers.

Recently, the new talent-based economy leads to a workforce shift because of the automation that results in changes in skill requirements and increases the constraints of hiring new workers, especially youth. Traditional school-to-work channels and skills training models are no longer used to guide youth towards sustainable careers. The efficiency of the new talent-based economy means that not enough jobs will be available for all youth who wish to work. This makes it more important to focus on practical and realistic strategies to create jobs for youth in order to avoid a lost generation of youth in all countries (ManpowerGroup 2012).

In studying the channels those can connect FDI to affect unemployment, the literature has given many direct and indirect channels. These channels can relate unemployment to FDI improvements whether negatively or positively (Adeyemi 2018; Barkauskaite and Naraskeviciute 2016; Brincikova and Darmo 2014; Haddad 2016; Matthew and Johnson 2014; Mayom 2015; Jaouadi 2014; Zeb, Qiang, and Sharif 2014).These channels affect not only the quantity of employment, but it also affects the quality of them. Table (1) summarizes these channels. 
It is clear from table (1) that the negative effect of FDI on unemployment cannot be automatically assured, as this effect can be very diverse depending on the country features including demographic age structure, the period of study, the chosen mode of foreign investment entry, and the dominant form of unemployment in the country (Balcerzak and Zurek 2011; Haddad 2016; Irpanet al. 2016; Strat et al. 2015; Vacaflores 2011)).

Table 1: The channels of affecting unemployment through FDI

\begin{tabular}{|c|c|c|c|}
\hline \multicolumn{2}{|c|}{ Direct } & \multicolumn{2}{|c|}{ Indirect } \\
\hline $\begin{array}{c}\text { Negative } \\
\text { production } \\
\text { capacity creates } \\
\text { jobs }\end{array}$ & $\begin{array}{c}\text { Relying less on } \\
\text { labor intensive } \\
\text { technologies }\end{array}$ & $\begin{array}{c}\text { Induced exports } \\
\text { effects on labor }\end{array}$ & $\begin{array}{c}\text { Reducing wages in } \\
\text { local firms to } \\
\text { support competition }\end{array}$ \\
\hline $\begin{array}{c}\text { Increasing wages } \\
\text { because of } \\
\text { enhancing } \\
\text { productivity }\end{array}$ & $\begin{array}{c}\text { The tendency of } \\
\text { domestic firms to } \\
\text { reduce } \\
\text { employment }\end{array}$ & $\begin{array}{c}\text { Facilitated } \\
\text { technology } \\
\text { transfer improves } \\
\text { demand }\end{array}$ & $\begin{array}{c}\text { Unfair competition } \\
\text { and local producers } \\
\text { lose their markets }\end{array}$ \\
$\begin{array}{c}\text { Closing the gap in } \\
\text { local resources } \\
\text { creates jobs in } \\
\text { expanding firms }\end{array}$ & $\begin{array}{c}\text { Mergers and } \\
\text { buys privatized } \\
\text { enterprises may } \\
\text { result in job } \\
\text { losses }\end{array}$ & $\begin{array}{c}\text { Job creation due } \\
\text { to forward and } \\
\text { backward } \\
\text { linkages and } \\
\text { multiplier effects }\end{array}$ & $\begin{array}{c}\text { Price distortions or } \\
\text { misallocations of } \\
\text { resources affect the } \\
\text { demand for labor }\end{array}$ \\
\hline $\begin{array}{c}\text { Green field } \\
\text { investments } \\
\text { create more jobs }\end{array}$ & $\begin{array}{c}\text { Crowding out of } \\
\text { domestic } \\
\text { relatively labor } \\
\text { intensive firms }\end{array}$ & $\begin{array}{c}\text { Enhanced } \\
\text { competition } \\
\text { improves the } \\
\text { demand }\end{array}$ & $\begin{array}{c}\text { Regional } \\
\text { imbalances due to } \\
\text { immigration to } \\
\text { urban areas }\end{array}$ \\
\hline $\begin{array}{c}\text { Human capital } \\
\text { and labor } \\
\text { productivity } \\
\text { growth }\end{array}$ & $\begin{array}{c}\text { Not efficient and } \\
\text { low-skilled } \\
\text { workers loses } \\
\text { their jobs }\end{array}$ & $\begin{array}{c}\text { "Best practices" } \\
\text { spread to local } \\
\text { businesses }\end{array}$ & $\begin{array}{c}\text { The greater reliance } \\
\text { on imported inputs } \\
\text { and components }\end{array}$ \\
\hline
\end{tabular}

Source: Prepared by the researcher based on the literature.

\subsection{Empirical Review}

Empirical studies confirm that the effects of FDI trends on unemployment are not guaranteed. Although there are a large number of studies that confirm more or less the negative relationship, some studies have found a positive and significant relationship between them. Matthew and Johnson (2014) proved 
that empirical results for this effect are sensitive to data treatment and model specifications.

Most of the studies that confirm the negative effects of FDI trends on unemployment were applied on developed countries. However, a number of empirical studies approved the negative relationship for developing countries. This study will focus on this relationship in the developing countries which the countries under this study are belonging to.

Vacaflores (2011) studied the effect of FDI on employment in a group of Latin American countries in the period 1980-2006 using a dynamic panel model. The study confirmed the positive and significant effect between them. The study stated that the effect of FDI to reduce unemployment is greater for countries with high level of informality and those attracting low average of FDI.

Balcerzak and Zurek (2011) analyzed the influence of FDI on labor markets in Poland using VAR methodology for the period 1995-2009. The study proved that attracting FDI leads to decreasing unemployment rate in Poland. However, the positive effect of FDI on Polish employment tends to be rather short-term. Accordingly, they suggested that adjustments should be made to Polish government policies that promote FDI so as to promote the positive impact on employment over the long run.

Habib and Sarwar (2013) assessed the long-term relationship between FDI and employment in Pakistan from 1970 to 2011 using Johanson Co-integration approach. The results confirmed the existence of long -term relationship as FDI enhances employment opportunities and reduce unemployment in Pakistan.

Matthew and Johnson (2014) examined the relationship between FDI and unemployment using different specifications of the model for Nigeria. Results of both of the traditional OLS and the standardize regression models confirmed the negative effect of 
FDI on Nigerian unemployment growth rate. Moreover, the study of Granger causality test proved that the relationship between FDI and Nigerian unemployment growth rate goes in both directions.

Kurtovicet al. (2015) investigated the long-term relationship between FDI and unemployment in six countries of the Western Balkans (WB) using panel data from 1998 to 2012. The study confirmed the negative long-term impact of FDI on unemployment in Bosnia and Herzegovina, Croatia, Macedonia, and Montenegro.

Mayom (2015) scrutinized the impact of FDI on employment using panel data set of 48 Sub-Saharan African Countries during the period 1991-2009. The results indicate that FDI has a positive and significant effect on employment; consequently it is related negatively to unemployment. Hence, the study advised SubSaharan African governments to focus on attracting FDI to the industries where it can significantly reduce unemployment.

Irpan et al. (2016) investigated the long-term relationship between FDI on employment rate in Malaysia from 1982 to 2012 using Autoregressive distributed lag (ARDL) model. The findings of the study confirmed that FDI significantly reduces the unemployment rate.

Johnny et al. (2018) tested the impact of FDI on unemployment rate in Nigeria from 1980 to 2015 using co-integration analysis. The findings indicate that FDI is found to be negatively related to unemployment rate.

Adeyemi (2018) scrutinized the impact of FDI on employment generation in Nigeria from 1999 to 2016 using the OLS method. The results confirm the positive and significant relationship between FDI and employment generation in Nigeria. Consequently, the paper stated that attracting FDI to Nigeria contributed in reducing unemployment. 
However, many studies have failed to demonstrate the negative and significant relationship between FDI and unemployment; most of these studies have been applied to developing and less developed countries.

Rizvi and Nishat (2009) tested the effects of FDI on employment creation in three countries i.e. Pakistan, India and China over the period of 1985-2008 using a balanced panel data model. The study failed to prove the negative relationship between FDI and unemployment. Accordingly, the study concluded that the policies to promote FDI must be complemented by other measures to stimulate employment growth.

Mucuk and Demirsel (2013) studied the long-term relationship between FDI and unemployment for seven developing countries from 1981 to 2009 using panel co-integration analysis. The findings prove that attracting FDI increases unemployment in Argentina and Turkey and it failed to prove the relationship in Chile, Philippines, Colombia, and Uruguay. This is explained for Argentina and Turkey by the fact that the majority of foreign investment has the shape of Brownfield investments which is generally composed of mergers and acquisitions instead of Green field investments. Kurtovicetal.(2015), in a study mentioned earlier, found that the long-term relationship between FDI and unemployment in both of Albania and Serbia is not proved for the same explanation.

Brincikova and Darmo (2014) investigated the effects of FDI on unemployment in V4 countries in the period 1993-2012 using panel data. The study dealt with the macroeconomic perspective because of the lack of data about different types of investment. The results show that there is no statistical significant impact of FDI on unemployment. 
Strat et al. (2015) studied the short-term causal relationship between FDI and unemployment as a proxy for the macroeconomic stability for the latest thirteen member states of the EU from 1991 to 2012.The findings of the paper confirmed a one-way causality from the FDI towards unemployment in only four of the thirteen members, namely: Hungary, Malta, Bulgaria, and Estonia.

Barkauskaite and Naraskeviciute (2016) tested the effects of FDI on economic indicators in the Baltic Countries during the period of 2000-2012. The study found that even though the effects of FDI on both of gross domestic product (GDP) and labor productivity growth proved to be significant, it failed to prove the relationship between FDI and the unemployment rate.

Grahovac and Softic (2017) explored the effects of FDI on unemployment rates in the Western Balkan countries from 2000 to 2014 using a multiple linear regression model. The Results stressed on the absence of having a negative impact of FDI on unemployment in all Western Balkan countries with an exception of Croatia. However, the unemployment rate is still high in it. Zdravkovic, Dukic, and Bradic-Martinovic (2017) investigated the long-term relationship between FDI per capita and unemployment rates in 17 transition countries over the period 2000-2014 using panel cointegration approach. Results of the estimation suggested that both of FDI and unemployment are not co-integrated. Hence, the study confirmed that the long-term effect of FDI on unemployment in transition economies does not exist.

As mentioned above, few of the empirical researches focus on the impact of FDI on youth unemployment rate in developing countries. As in the case of national unemployment, empirical researchers do not agree about the direction of the effect from FDI flows on youth unemployment changes. 
Haddad (2016) explored the impact of FDI on both of unemployment rate and economic growth in Jordan during the period 1998-2014 using OLS regression. Their main conclusion is that youth and high educated people are the largest form of unemployment in Jordan. The empirical study proved that even though FDI is not the main factor affecting unemployment in Jordan, it can help reducing unemployment.

Jaouadi (2014) estimated the possibility of causality, long-term and short-term relationships between FDI and unemployment of male youth in KSA during the period $1991-2012$. The results confirmed the negative effects of FDI on KSA including the labor market. FDI is found to affect the employment of youth negatively. The study explained this negative relationship by the inefficient policies adopted by the Saudi government including the limitations on the imported labor and limiting the ability of foreigners to change careers.

From the study of empirical studies of the effects of FDI on unemployment, whether national or youth, it was clear that the studies did not agree on the direction or the significance of the relationship conclusively. This confirms the findings of the literature that several factors affect this relationship. This requires studying the effects of FDI on unemployment in the case of the Arab countries identified above in the coming sections.

\section{Data sources, Specification of the Model, and Estimation strategy}

In this section, the description of data, sources, specification of the model, and estimation strategy used to estimate the impact of FDI on national and youth unemployment rates are performed. 


\subsection{Data sources}

Eight Arab countries are selected for this study based on the suffering from relatively high unemployment rates during the period 1991-2017. Data are gathered from World Development Indicators of the World Bank and International Labor Organization database (ILOSTAT) and World Economic Outlook. All variables data are converted to natural logarithms except for those with negative values. The description of data is introduced in table 2 .

Table 2: The description of data included in the model

\begin{tabular}{|l|c|c|c|c|c|c|}
\hline & LUNEM_ & LY_UNEM & LPOP_ & FDI_ & INF_ & RGDP_ \\
\hline Mean & 2.49 & 3.26 & 16.46 & 3.84 & 10.72 & 4.1287 \\
\hline Median & 2.52 & 3.32 & 16.55 & 2.24 & 5.13 & 3.800 \\
\hline Maximum & 3.39 & 3.95 & 18.39 & 37.17 & 159.2 & 38.200 \\
\hline Minimum & 1.81 & 2.73 & 14.55 & -0.59 & -11.18 & -17.900 \\
\hline Std. Dev. & 0.32 & 0.31 & 1.11 & 4.95 & 20.18 & 4.125 \\
\hline Skewness & 0.34 & 0.01 & -0.062 & 2.93 & 4.36 & 2.121 \\
\hline Kurtosis & 3.31 & 2.14 & 1.67 & 15.18 & 25.54 & 27.28 \\
\hline \hline Jarque-Bera & 4.92 & 6.65 & 16.08 & 1644 & 5261 & 5467.07 \\
\hline Probability & 0.085 & 0.0359 & 0.0003 & 0.00 & 0.00 & 0.00 \\
\hline Sum & 539.7483 & 703.0146 & 3555.8 & 828.5 & 2316 & 891.8 \\
\hline Sum Sq. Dev. & 21.96 & 20.18 & 266.2 & 5279 & 87575 & 3658.5 \\
\hline \hline Observations & 216 & 216 & 216 & 216 & 216 & 216 \\
\hline \hline
\end{tabular}

Source: Prepared by the researcher based on the literature.

\subsection{Specification of the Model}

In estimating the model, a panel unit root, panel cointegration and Granger causality tests are used to analyze the main determinants of both of national unemployment rate (unem) and youth unemployment rate (y_unem) in the eight Arab countries. Both dependent variables are determined using the independent variables including net inflows of foreign direct investment as a percentage of GDP (FDI), total population (pop), annual real GDP growth (RGDP), a set of time dummies $\left(\lambda_{t}\right)$, and country 
fixed effect $\left(\beta_{\mathrm{i}}\right)^{6}$.Consequently, taking into account the lack of data on real wages and interest rates in the countries under study and that the FDI is already included in the investment component of the GDP, the model was built as follows:

$\ln$ unem $_{i t}=\beta_{0}+\beta_{1} F D I_{i t}+\beta_{2} \ln P_{o p}+\beta_{3} R G D P_{i t}+\lambda_{i}+\varepsilon_{i t}$

$\ln y_{-}$unem $_{i t}=\gamma_{0}+\gamma_{1} F D I_{i t}+\gamma_{2} \ln$ Pop $_{i t}+\gamma_{3} R G D P_{i t}+\theta_{i}+\xi_{i t}$

In equations (1) and (2), subscript $\mathrm{i}(\mathrm{i}=1,2, \ldots, \mathrm{N})$ denotes the cross-sections while $\mathrm{t}(\mathrm{t}=1,2, \ldots ., \mathrm{T})$ refers to time period. $\lambda_{i}$ and $\theta_{i}$ are sets of individual and time-invariant country's fixed effect and $\varepsilon_{i t}$ and $\xi_{i t}$ stand for the error terms.

\subsection{Estimation strategy}

In estimating panel unit roots of variables included in equations 1 and 2, tests of Levin, Lin and Chu (LLC), Im, Peseran and Shin (IPS), Fisher-type-ADF (FT), Harris-Tzavalis (HT), and Hadri are used. They all test the null of having unit roots in all panels against the alternative of the stationarity of them all in the following $\mathrm{ADF}$ process for panel data model, where $\mathrm{X}_{\mathrm{it}}$ refers to a vector of exogenous variables including fixed effects and individual trends (Hlouskova and Wagner 2006).

$$
\Delta y_{i t}=\alpha_{i} y_{i t-1}+\sum_{j=1}^{\rho_{i}} \beta_{i j} \Delta y_{i t-j}+\mathrm{X}_{i t}^{\prime} \varphi+\tau_{i t}
$$

These tests are divided into two groups. The first one assumes a common autoregressive coefficients $\alpha_{\mathrm{i}}=\alpha$ in equation (3) where $\alpha$ $=\rho-1$. Therefore, the null hypotheses can be written as H0: $\alpha=$ 0 . This group of tests includes LLC, HT, and Hardi tests. The second group of tests allows for heterogeneous $\rho_{i}$ and so $\alpha_{i}$ across cross-sections. The Im, Pesaran, and Shin (IPS), and Fisher-ADF are of this form. The null hypotheses for these tests can be written 
as H0: $\alpha_{\mathrm{i}}=0$, for all $\mathrm{i}$ (Breitung and Pesaran 2005; Hlouskova and Wagner 2006).

Panel cointegration test is used to examine the long-term relationship between variables. Pedroni, Kao Residual, and Fisher Combined Johansson tests are performed. Pedroni and Kao Residual panel cointegration tests are residual-based tests ${ }^{7}$. Both are panel equivalent to the test of Engle-Granger for integration used for time series analysis (Kurtovic et al. 2015). Pedroni submit seven tests in two groups, the first group consists of three group-mean tests and the other four are pooled tests. The two groups of tests have the same null hypothesis of no cointegration while having different alternative hypothesis. Both of Pedroni and Kao tests are based on examining the residuals of regressing I(1) panel data variables (Breitung and Pesaran 2005). If these variables are cointegrated then the residuals should be stationary. Considering the following model:

$$
y_{i t}=\alpha_{i}+\delta_{i} t+\beta_{i j} \sum_{j=1}^{M} x_{i j, t}+\varepsilon_{i t}
$$

In equation (4), $\mathrm{t}$ refers to time, $\mathrm{j}$ is the number of explanatory variables, $x$ expresses a vector of explanatory variables those are assumed to be I(1), $\alpha_{i}$ captures individual effects, and $\delta_{i}$ refers to trend effect. Accordingly, both of Pedroni and Kao tests inspect the null hypothesis of no cointegration in the error term of equation (4), meaning that $\left(\rho_{i}=1\right)$ in equation (5).Fisher Combined Johansson test gathers individual cointegration tests of cross-sections to obtain a test that fits with panel.

$$
\varepsilon_{i t}=\rho_{i} \varepsilon_{i t-1}+u_{i t}
$$

If variables are proven to be cointegrated for both models shown in equations (1) and (2), the next step should be to estimate the

\footnotetext{
${ }^{7}$ Pedroni test consists of eleven statistics with differences in power and size for different sizes of identifiers and time length. Kao test follows the same methodology with one difference which is assuming $\alpha_{i}$ to be heterogeneous and $\beta_{i}$ to be homogeneous across cross-sections.
} 
associated cointegrating vector of parameters referring to the long-term relationships. Kao and Chiang (2001) argue that OLS leads to biased and inconsistent estimators of parameters in case of non-stationary panels. Alternatively, it is recommended to use "fully modified OLS" (FMOLS) and "parametric panel dynamic OLS"(DOLS) estimators to have more promising estimates for the cointegrating vector of parameters (Breitung and Pesaran 2005). FMOLS obtains an "asymptotically efficient estimator" in case of homogenous cointegration vectors. It corrects the effects of both of long-term endogenous regressors and short-term dynamics of errors through adjusting the dependent variable to neutralize the impact of the part of error that is correlated with the regressors. DOLS estimator works to disassemble the error term. So, the error term of equation (4) can be rewritten as:

$$
\varepsilon_{i t}=\sum_{k=-\infty}^{\infty} \gamma^{\prime} \Delta x_{i, t}+k+\xi_{i t}
$$

Where $\xi_{i t}$ is orthogonal to all lags and leads of $\Delta x_{i t}$.In practice, the infinite sums of leads and lags in equation (6) are truncated at some small numbers.

Panel vector error correction model (VECM) is used to study the speed of adjustment towards the long-term equilibrium in both equations. Then the short-term causality between FDI and both of national unemployment and youth unemployment are tested using Wald test. To confirm the causality, Granger Causality Test is used.

\section{Empirical Results}

Following the description of the variables and the econometric method used tests of a panel unit root, panel cointegration and Granger causality test are implemented to estimate equations (1) and (2). 
Tests of Levin, Lin and Chu (LLC), Im, Peseran and Shin (IPS), Fisher-type-ADF (FT), Harris-Tzavalis (HT), and Hardiare used to investigate panel unit root tests. Results give calculated $p$-values those confirmed the stationary of the first difference of the variables.

In order to test the long-term relationship in both models included in equations (1) and (2), Pedroni, Kao Residual, and Fisher Combined Johansson tests are performed. Tables (3) and (4) summarize the results of Kao and Pedroni Residual Cointegration Tests for variables included in equations (1) and (2).

Table 3: Kao Residual Panel Cointegration Test

\begin{tabular}{|c|c|c|c|c|}
\hline \multicolumn{5}{|c|}{ Included observations: 27} \\
\hline \multicolumn{5}{|c|}{ Null Hypothesis: No cointegration } \\
\hline \multicolumn{5}{|c|}{ Trend assumption: No deterministic trend } \\
\hline \multicolumn{5}{|c|}{ Automatic lag length selection based on SIC with a max lag of 2} \\
\hline \multicolumn{5}{|c|}{ Newey-West automatic bandwidth selection and Bartlett kernel } \\
\hline \multirow[t]{2}{*}{ Series } & \multicolumn{2}{|c|}{$\begin{array}{l}\text { lnunem,fdi,lnPop, and } \\
\text { RGDP }\end{array}$} & \multicolumn{2}{|c|}{$\begin{array}{l}\text { lny_unem, fdi, lnPop, and } \\
\text { RGDP }\end{array}$} \\
\hline & t-Statistic & Prob. & t-Statistic & Prob. \\
\hline $\mathrm{ADF}$ & 0.260365 & 0.3973 & -0.03012 & 0.4880 \\
\hline $\begin{array}{l}\text { Res. } \\
\text { variance }\end{array}$ & 0.006133 & & 0.007242 & \\
\hline $\begin{array}{l}\mathrm{HAC} \\
\text { variance }\end{array}$ & 0.008051 & & 0.006757 & \\
\hline
\end{tabular}

Source: Prepared by the researcher based on the estimation.

Table (3) of Kao Residual Test emphasizes the absence of cointegration in both models. In table (4), p-value of PedroniPanel Cointegration Test for six out of the eleven tests reject the null hypothesis of no cointegration for national unemployment rate while only three tests reject the null hypothesis for youth unemployment rate. This emphasizes a longterm relationship between the variables for national 
unemployment while rejecting this long-term relationship for youth unemployment.

In order to confirm the existence of the long-term relationships between variables included in equations (1) and (2), Fisher Combined Johansson test is performed. Table (5) summarizes the results of Fisher Combined Johansson test.

Table 4: Pedroni Panel Cointegration Test

\begin{tabular}{|c|c|c|c|c|c|c|c|c|}
\hline \multicolumn{9}{|c|}{ Included observations: 27} \\
\hline \multicolumn{9}{|c|}{ Cross-sections included: 8} \\
\hline \multicolumn{9}{|c|}{ Null Hypothesis: No cointegration } \\
\hline \multicolumn{9}{|c|}{ Trend assumption: Deterministic intercept and trend } \\
\hline \multicolumn{9}{|c|}{ Automatic lag length selection based on SIC with a max lag of 2} \\
\hline \multicolumn{9}{|c|}{ Newey-West automatic bandwidth selection and Bartlett kernel } \\
\hline \multicolumn{9}{|c|}{ Alternative hypothesis: common AR coefs. (within-dimension) } \\
\hline \multirow[t]{2}{*}{ Series: } & \multicolumn{4}{|c|}{ lnunem, fdi, lnPop, and RGDP } & \multicolumn{4}{|c|}{ lny_unem, fdi, lnPop, and RGDP } \\
\hline & Stat. & Prob & $\begin{array}{c}\text { WeightedStatisti } \\
\underline{\mathrm{c}}\end{array}$ & Prob & Stat. & Prob & $\begin{array}{c}\text { WeightedStatisti } \\
\underline{\mathrm{c}} \\
\end{array}$ & Prob \\
\hline $\begin{array}{l}\text { Panel } \\
\text { v- } \\
\text { Statisti } \\
\text { c } \\
\end{array}$ & $\begin{array}{c}0.9 \\
4 \\
\end{array}$ & $\begin{array}{l}0.1 \\
7\end{array}$ & -0.86 & $\begin{array}{c}0.8 \\
1\end{array}$ & $\mid \begin{array}{l}- \\
0.47\end{array}$ & $\begin{array}{l}0.6 \\
8\end{array}$ & -1.03 & $\begin{array}{c}0.8 \\
5\end{array}$ \\
\hline $\begin{array}{l}\text { Panel } \\
\text { rho- } \\
\text { Statisti } \\
\text { c }\end{array}$ & $\begin{array}{l}0.0 \\
4\end{array}$ & $\begin{array}{l}0.5 \\
2\end{array}$ & -1.56 & $\begin{array}{l}0.0 \\
6\end{array}$ & $\begin{array}{c}1.0 \\
6\end{array}$ & $\begin{array}{c}0.8 \\
6\end{array}$ & -0.83 & $\begin{array}{c}0.2 \\
0\end{array}$ \\
\hline $\begin{array}{l}\text { Panel } \\
\text { PP- } \\
\text { Statisti } \\
\text { c }\end{array}$ & 2.12 & $\begin{array}{l}0.0 \\
2\end{array}$ & -5.69 & $\begin{array}{l}0.0 \\
0\end{array}$ & $\mid-$ & $\begin{array}{l}0.2 \\
2\end{array}$ & -3.82 & $\begin{array}{c}0.0 \\
0\end{array}$ \\
\hline $\begin{array}{l}\text { Panel } \\
\text { ADF- } \\
\text { Statisti } \\
\text { c }\end{array}$ & - & $\begin{array}{l}0.0 \\
3\end{array}$ & -5.57 & $\begin{array}{l}0.0 \\
0\end{array}$ & $\mid-\overline{-}$ & $\begin{array}{l}0.2 \\
3\end{array}$ & -3.54 & $\begin{array}{c}0.0 \\
0\end{array}$ \\
\hline Alternat & ve hy & othes & s: individual AR & oefs. & betwee & en-dim & ension) & \\
\hline $\begin{array}{l}\text { Group } \\
\text { rho- } \\
\text { Statisti } \\
\text { c }\end{array}$ & $\begin{array}{l}0.1 \\
7 \\
\end{array}$ & $\begin{array}{l}0.5 \\
7\end{array}$ & & & 0.45 & 0.67 & & \\
\hline $\begin{array}{l}\text { Group } \\
\text { PP- }\end{array}$ & 3.92 & $\begin{array}{c}0.0 \\
0\end{array}$ & & & |-2.57 & 0.01 & & \\
\hline
\end{tabular}




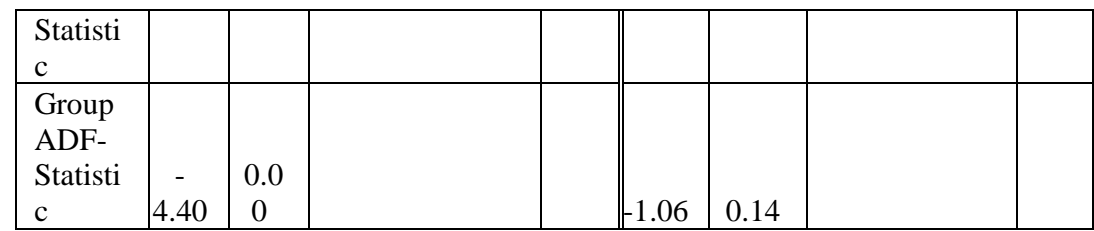

Source: Prepared by the researcher based on the estimation.

Table (5) of the Fisher Combined Johansson test indicates that there are long-term relationships in equations (1) and (2) as results illustrate a $p$-value that confirmed the existence of at most three cointegration vectors.

Table 5: Fisher Combined Johansson Test for national unemployment model

\begin{tabular}{|c|c|c|c|c|c|c|c|c|}
\hline \multicolumn{9}{|c|}{ Johansen Fisher Panel Cointegration Test } \\
\hline \multicolumn{9}{|c|}{ Sample: 19912017} \\
\hline \multicolumn{9}{|c|}{ Included observations: 27} \\
\hline \multicolumn{9}{|c|}{ Trend assumption: Linear deterministic trend } \\
\hline \multicolumn{9}{|c|}{ Lags interval (in first differences): 11} \\
\hline \multicolumn{9}{|c|}{ Unrestricted Cointegration Rank Test (Trace and Maximum Eigenvalue) } \\
\hline Model & Series: & $\begin{array}{r}\text { iunem, } \\
\mathrm{RC} \\
\end{array}$ & $\begin{array}{l}\mathrm{Pi}, \ln \mathrm{Pop} \\
\mathrm{P}\end{array}$ & & Series: & $\begin{array}{r}\text { y_uner } \\
\mathrm{RC} \\
\end{array}$ & $\begin{array}{l}\text { 1, fdi, } \ln \mathrm{Pol} \\
\text { DP }\end{array}$ & and \\
\hline $\begin{array}{l}\text { Hypoth. } \\
\text { No. of } \\
\text { CE(s) }\end{array}$ & \begin{tabular}{||c} 
Fisher \\
Stat. $^{*}$ \\
trace test
\end{tabular} & Prob. & $\begin{array}{l}\text { Fisher } \\
\text { Stat. } \\
\text { (max- } \\
\text { eigen } \\
\text { test) }\end{array}$ & Prob. & $\begin{array}{c}\text { Fisher } \\
\text { Stat. }^{+} \\
\text {(trace }^{-} \\
\text {test) }\end{array}$ & Prob. & $\begin{array}{c}\text { Fisher } \\
\text { Stat. }^{+} \\
\text {(max- }^{-} \\
\text {eigen test) }\end{array}$ & Prob. \\
\hline None & 201.1 & 0.00 & 164.0 & 0.00 & 189.9 & 0.00 & 151.5 & 0.00 \\
\hline At most 1 & 70.02 & 0.00 & 53.21 & 0.00 & 70.85 & 0.00 & 51.13 & 0.00 \\
\hline At most 2 & 32.65 & 0.01 & 34.53 & 0.01 & 35.10 & 0.00 & 34.60 & 0.01 \\
\hline At most 3 & 14.70 & 0.55 & 14.70 & 0.55 & 19.82 & 0.23 & 19.82 & 0.23 \\
\hline
\end{tabular}

* Probabilities are computed using asymptotic Chi-square distribution.

+ MacKinnon-Haug-Michelis (1999) p-values

Source: Prepared by the researcher based on the estimation. 
In conclusion, two tests of cointegration out of three confirmed the long-term relationship for national unemployment while rejecting this long-term relationship for youth unemployment. As the long-term relationship for national unemployment is confirmed, long-term endogeneity of independent variables is tested using Wald test. Table (6) summarizes the results of Wald test.

Table 6: Wald test of Endogeneity

\begin{tabular}{|c|c|c|c|c|c|c|}
\hline \multirow{2}{*}{$\begin{array}{c}\text { Test } \\
\text { Statistic }\end{array}$} & \multicolumn{2}{|c|}{ rgdp } & \multicolumn{2}{c|}{ fdi } & \multicolumn{2}{c|}{ lpop } \\
\cline { 2 - 7 } & Value & Prob. & Value & Prob. & Value & Prob. \\
\hline t-statistic & 0.063 & 0.949 & 0.839 & 0.402 & 2.359 & 0.019 \\
\hline F-statistic & 0.004 & 0.949 & 0.704 & 0.402 & 5.565 & 0.019 \\
\hline Chi-square & 0.004 & 0.949 & 0.704 & 0.401 & 5.565 & 0.018 \\
\hline
\end{tabular}

Source: Prepared by the researcher based on the estimation.

Table (6) of Wald test refers to that while RGDP and FDI are exogenous, population is endogenous. This leads to estimate the associated long-term cointegration parameters for national unemployment model using DOLS and FMOLS to obtain asymptotically unbiased and consistent estimates of the cointegrating vectors. Especially, if we put into consideration that theoretically the causal relationship between unemployment and RGDP growth runs in both directions. Table (7) summarizes the results of DOLS and FMOLS for panel and country-specific data.

Table 7: Results of DOLS and FMOLS estimators

\begin{tabular}{|c|c|c|c|c|c|c|c|}
\hline \multicolumn{8}{|c|}{ Dependent Variable: LUNEM } \\
\hline \multirow[t]{2}{*}{ Method } & \multicolumn{4}{|c|}{ DOLS estimator } & \multicolumn{3}{|c|}{ FMOLS estimator } \\
\hline & Variables & fdi & lnPop & RGDP & fdi & lnPop & RGDP \\
\hline \multirow{2}{*}{ Group } & Coeff. & 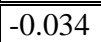 & 0.153 & 0.028 & 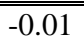 & 0.152 & 0.009 \\
\hline & $\mathrm{P}$-value & 0.000 & 0.000 & 0.001 & 0.002 & 0.000 & 0.101 \\
\hline \multirow{2}{*}{ ALG } & Coeff. & -0.156 & 0.431 & -0.24 & -0.22 & 0.169 & 0.034 \\
\hline & P-value & 0.718 & 0.000 & 0.021 & 0.257 & 0.000 & 0.591 \\
\hline \multirow{2}{*}{ EGY } & Coeff. & 0.031 & 0.106 & -0.09 & 0.019 & 0.144 & -0.07 \\
\hline & P-value & 0.011 & 0.006 & 0.003 & 0.229 & 0.000 & 0.003 \\
\hline \multirow{2}{*}{ JOR } & Coeff. & -0.02 & 0.176 & 0.058 & -0.02 & 0.165 & 0.049 \\
\hline & P-value & 0.0007 & 0.000 & 0.001 & 0.00 & 0.000 & 0.000 \\
\hline LEB & Coeff. & \begin{tabular}{|l|}
0.008 \\
\end{tabular} & 0.169 & \begin{tabular}{|c|}
-0.01 \\
\end{tabular} & -0.00 & 0.129 & 0.017 \\
\hline
\end{tabular}




\begin{tabular}{|l|c|c|c|c||c|c|c|}
\hline & P-value & 0.0842 & 0.000 & 0.418 & 0.64 & 0.000 & 0.180 \\
\hline \multirow{2}{*}{ MAU } & Coeff. & -0.006 & 0.086 & 0.011 & -0.01 & 0.159 & 0.002 \\
\cline { 2 - 8 } & P-value & 0.215 & 0.108 & 0.288 & 0.01 & 0.000 & 0.6506 \\
\hline \multirow{2}{*}{ MOR } & Coeff. & -0.153 & 0.073 & 0.136 & -0.21 & 0.166 & -0.01 \\
\cline { 2 - 8 } & P-value & 0.002 & 0.046 & 0.032 & 0.000 & 0.000 & 0.974 \\
\hline \multirow{2}{*}{ SUD } & Coeff. & 0.0153 & 0.116 & 0.002 & -0.01 & 0.149 & 0.009 \\
\cline { 2 - 8 } & P-value & 0.0074 & 0.000 & 0.205 & 0.189 & 0.000 & 0.001 \\
\hline \multirow{2}{*}{ TUN } & Coeff. & -0.086 & 0.186 & 0.011 & -0.05 & 0.176 & 0.003 \\
\cline { 2 - 8 } & P-value & 0.059 & 0.000 & 0.720 & 0.005 & 0.000 & 0.83 \\
\hline
\end{tabular}

Source: Prepared by the researcher based on the estimation.

As DOLS and FMOLS models confirmed the existence of the cointegration for national unemployment, panel vector error correction model (VECM) is used to study the speed of adjustment towards the long-term equilibrium for this model. Moreover, the short-term causality between FDI and both of national unemployment is tested using Wald test. Tables (8) and (9) show the results of Panel vector error correction for national unemployment model and Wald test for that model respectively.

Table 8: Panel VECMfor national unemployment model

\begin{tabular}{|c|c|c|c|c|}
\hline \multirow{2}{*}{\multicolumn{2}{|c|}{$\begin{array}{l}\text { Vector Error Correction Estimates } \\
\text { Included observations: } 192 \text { after } \\
\text { adjustments }\end{array}$}} & \multicolumn{3}{|c|}{ Sample (adjusted): 19942017} \\
\hline & & \multicolumn{3}{|c|}{ Standard errors in ( ) \& t-statistics in [ ] } \\
\hline Cointegrating Eq. & CointEq1 & Standard error & t-statistics & \\
\hline Lag dependant var. & 1.00 & & & \\
\hline FDI_(-1) & 0.728 & $(0.130)$ & {$[5.594$} & \\
\hline LPOP_(-1) & -0.108 & $(0.489)$ & {$[-0.22]$} & \\
\hline RGDP_(-1) & 0.590 & $(0.211)$ & [2.796] & \\
\hline $\mathrm{C}$ & -6.098 & & & \\
\hline Error Correction: & D(LUNEM_) & $\mathrm{D}(\mathrm{FDI})$ & $\mathrm{D}\left(\mathrm{LPOP} \_\right)$ & D(RGDP_) \\
\hline CointEq1 & $\begin{array}{l}-0.001 \\
(0.001) \\
{[-0.665]}\end{array}$ & $\begin{array}{l}-0.315 \\
(0.073) \\
{[-4.301]}\end{array}$ & $\begin{array}{c}0.000 \\
(3.5 \mathrm{E}-05) \\
{[5.302]} \\
\end{array}$ & $\begin{array}{c}-0.18792 \\
(0.066) \\
{[-2.819]} \\
\end{array}$ \\
\hline D(LUNEM_(-1)) & $\begin{array}{r}0.0831 \\
(0.072) \\
{[1.141]} \\
\end{array}$ & $\begin{array}{l}-0.645 \\
(3.371) \\
{[-0.191]} \\
\end{array}$ & $\begin{array}{c}-0.00133 \\
(0.002) \\
{[-0.842]} \\
\end{array}$ & $\begin{array}{c}2.771103 \\
(3.059) \\
{[0.905]} \\
\end{array}$ \\
\hline D(LUNEM_(-2)) & $\begin{array}{r}0.024 \\
(0.073) \\
{[0.339]}\end{array}$ & $\begin{array}{r}-1.017 \\
(3.379) \\
{[-0.301]}\end{array}$ & $\begin{array}{r}-0.000 \\
(0.002) \\
{[-0.209]}\end{array}$ & $\begin{array}{c}-0.546 \\
(3.067) \\
{[-0.178]}\end{array}$ \\
\hline
\end{tabular}




\begin{tabular}{|c|c|c|c|c||}
\hline D(FDI_(-1)) & -0.000 & -0.029 & $-7.4 \mathrm{E}-05$ & 0.340 \\
& $(0.001)$ & $(0.073)$ & $(3.4 \mathrm{E}-05)$ & $(0.066)$ \\
& {$[-0.312]$} & {$[-0.404]$} & {$[-2.156]$} & {$[5.106]$} \\
\hline D(FDI_(-2)) & -0.000 & -0.191 & $-5.9 \mathrm{E}-05$ & 0.2764 \\
& $(0.001)$ & $(0.075)$ & $(3.5 \mathrm{E}-05)$ & $(0.067)$ \\
& {$[-0.074]$} & {$[-2.554]$} & {$[-1.698]$} & {$[4.069]$} \\
\hline D(LPOP_(-1)) & 0.454 & 14.018 & 1.7459 & -39.35 \\
& $(1.459$ & $(67.513)$ & $(0.032)$ & $(61.27)$ \\
& {$[0.311]$} & {$[0.207]$} & {$[55.041]$} & {$[-0.642]$} \\
\hline D(LPOP_(-2)) & 0.1272 & 2.509 & -0.883 & 40.741 \\
& $(1.404)$ & $(64.983)$ & $(0.030)$ & $(58.98)$ \\
& {$[0.091]$} & {$[0.039]$} & {$[-28.906]$} & {$[0.691]$} \\
\hline D(RGDP_(-1)) & -0.000 & 0.2025 & $-4.3 \mathrm{E}-05$ & -0.618 \\
& $(0.001)$ & $(0.077)$ & $(3.6 \mathrm{E}-05)$ & $(0.069)$ \\
& {$[-0.550]$} & {$[2.644]$} & {$[-1.2095]$} & {$[-8.894]$} \\
\hline D(RGDP_(-2)) & 0.001 & 0.1709 & $5.5 \mathrm{E}-06$ & -0.230 \\
& $(0.001)$ & $(0.061)$ & $(2.9 \mathrm{E}-05)$ & $(0.055)$ \\
& {$[0.451]$} & {$[2.796]$} & {$[0.19344]$} & {$[-4.153]$} \\
\hline C & -0.023 & -0.195 & 0.003 & -0.201 \\
& $(0.013)$ & $(0.604)$ & $(0.000)$ & $(0.547)$ \\
& {$[-1.766]$} & {$[-0.323]$} & {$[10.49]$} & {$[-0.367]$} \\
\hline \hline
\end{tabular}

Source: Prepared by the researcher based on the estimation.

Table 9: Results of Wald test

\begin{tabular}{|lccc|}
\hline Test Statistic & Value & df. & Probability \\
\hline Chi-square (LUNEM model) & 0.097384 & 2 & 0.9525 \\
\hline
\end{tabular}

Source: Prepared by the researcher based on the estimation.

Results of table (8) failed to confirm the speed of adjustment towards the long-term equilibrium for national unemployment as the error correction term coefficients negative but insignificant. The results of Wald test for both models are shown in table (9). Here, the results give probability greater than the critical value 0.05 referring to that the test cannot reject $\mathrm{H}_{0}$. This means that there is no short-term causality running from FDI to national unemployment. 
In order to confirm the absence of the short-term causality between FDI and national unemployment, Granger Causality Test is used as shown in table (10).

Based on the $p$-value, which gives values exceed the critical values of 0.05 , the short-term causal relationship in both directions is rejected between FDI and national unemployment.

Table 10: Results of Granger Causality test

Pairwise Granger Causality Tests

Sample: 19912017

Lags: 2

\begin{tabular}{|c|c|c|}
\hline Null Hypothesis: & Obs. F-Stat. & Prob. \\
\hline FD & $200 \quad 0.493$ & 511 \\
\hline LUNEM_does not Granger Cause FDI & 1.490 & 0.228 \\
\hline
\end{tabular}

Source: Prepared by the researcher based on the estimation.

\section{Results and policy implications}

In this paper, the macroeconomic impact of FDI on both of national unemployment and youth unemployment are investigated. The study included a number of Arab countries those suffer from relatively high unemployment rates during the period 1991-2017. In estimating the model, a panel unit root, panel cointegration and Granger causality tests are used. Tests of Levin, Lin and Chu (LLC), Im, Peseran and Shin (IPS), Fishertype-ADF (FT), Harris-Tzavalis (HT), and Hardi confirmed the stationary of the first difference of the variables. Even though Kao Residual tests emphasized the absence of a long-term relationship between the variables, both of Pedroni and Fisher Combined Johansson panel cointegration tests confirmed the long-term relationship for national unemployment while rejected this longterm relationship for youth unemployment. 
To estimate the associated long-term cointegration parameters for national unemployment model, both of DOLS and FMOLS are used. Results confirm the positive impact of FDI on reducing unemployment in the group as a whole and individually in Jordan, Morocco, and Tunisia while it leads to the increase of unemployment in Egypt. Panel vector error correction model (VECM) failed to prove the speed of adjustment towards the long-term equilibrium for national unemployment. Moreover, both of Wald and Granger Causality tests failed to prove the causal relationship in both directions between FDI and national unemployment.

A review of the results of the paper shows the need for more emphasis on directing FDI to labor-intensive sectors of disciplines and characteristics available in the country, especially in Egypt. It is possible to stimulate the positive impact of FDI on domestic employment by:

1. Focusing on Green field rather than Brownfield (Mergers and buys) investments is required.

2. Supporting the crowding in effects between foreign and domestic industries. Providing requirements for the local component within the foreign products produced within the country can be effective to strengthen the forward and backward linkages of the foreign investor with the local companies.

3. Emphasizing is placed on protecting local employment, especially from low-skilled workers. More stringent laws can be used to protect local labor. This should be applied to both of domestic and foreign enterprises.

4. Investing more in human capital so as to increase employment productivity over the long run. Wage rates can be raised to exceed marginal labor productivity in the short run as a labor incentive to reduce unemployment.

5. Focusing on the activation of competition laws and the prevention of monopolistic practices to ensure that national 
producers are protected from any non-competitive practices adopted by the foreign producer.

Conflict of Interest: The author declares that he has no conflict of interest.

\section{REFERENCES}

Adeyemi B. (2018).Foreign Direct Investment and Employment Generation in Nigeria.Journal of Economics and Sustainable Development, 9(4), 42-47.

Arnott R. J., Hosios, A., and Stiglitz, J. (1987). Implicit Contracts, Labor Mobility and Unemployment.NBER Working Paper, 2316.

Balcerzak, A. P. and M., Zurek (2011). Foreign Direct Investment and Unemployment: VAR Analysis for Poland in the Years 19952009.European Research Studies, 14(1), 3-12.

Barkauskaite, A. and V. Naraskeviciute.(2016).Foreign Direct Investment impact on economic indicators of Baltic countries. $D E$ Gruter Open, doi:10.1515/eb-2016-0009,2016/28. Retrieved from $<$ https://ortus.rtu.lv/science/en/publications/22102/attachme nts/734>(accessed July5, 2019).

Breitung, J. and M. H.,Pesaran (2005).Unit Roots and Cointegration in Panels.CESifo Working Paper Series no. 1565, CESifo Group Munich. Retrieved from<https://www.econstor.eu/bitstream/10419/19627/1/200542 dkp.pdf $>$ (accessed August 10, 2019).

Brincikova, Z. and L.,Darmo(2014). The Impact of FDI Inflow on Employment in V4Countries.European Scientific Journal, 1: 245-252.

Grahovac, D. and S.,Softic (2017).Impact of the FDI on Unemployment Rate in Countries of West Balkan.Review of Innovation and Competitiveness: A Journal of Economic and Social Research,3(2): 65-81. Retrieved from $<$ https://hrcak.srce.hr/file/273245> (accessed July19, 2019). 
Habib, M. D. and S., Sarwar (2013).Impact of foreign direct investment on employment level in Pakistan: A Time Series Analysis. Journal of Law, Policy and Globalization, 10, 46-55

HaddadA.M. (2016).Analysis of Foreign Direct Investment and Unemployment and Their Impact on Economic Growth in Jordan.International Journal of Investment Management and Financial Innovations,2(1), 1-12.

Hlouskova, J., and M., Wagner (2006). The Performance of Panel Unit Root and Stationarity Tests: Results from a Large Scale Simulation Study.EconometricReviews,25(1), 85-116.

Irpan, H. M., R. M. Saad, A. S. M.,Nor, A. M., Noor, and N., Ibrahim (2016).Impact of Foreign Direct Investment on the UnemploymentRateinMalyasia.Journal of Physics: Conference Series.

Retrieved

from $<$ https://iopscience.iop.org/article/10.1088/1742-

6596/710/1/012028/pdf > (accessed July 22, 2019).

Jaouadi S. (2014). Could foreign direct investment increase unemployment: case of KSA.RJEBS: TIJ's Research Journal of Economics \& Business Studies, 3(9), 51-56.

Johnny, N., E. T., Timipere, O., Krokeme, \& D. Markjackson (2018).Impact of Foreign Direct Investment on Unemployment rate in Nigeria (1980-2015).International Journal of Academic Research in Business and Social Sciences, 8(3), 57-69.

Kao, $C$. and M., Chiang(2001).On the estimation and inference of a cointegrated regression inpanel data.In Badi H. Baltagi (ed.), Nonstationary Panels, Panel Cointegration, and Dynamic Panels (Advances in Econometrics, Vol. 15), Emerald Group Publishing Limited, Bingley, pp. 179222,

Retrieved from $>$ http://citeseerx.ist.psu.edu/viewdoc/download?doi=10.1.1. $6.6161 \&$ rep $=$ rep $1 \&$ type $=p d f>($ accessed July 10, 2019).

Keynes, J. M. (1936). The general theory of employment, interest and money, New York: Harcourt, Brace.

Kurtovic S., B.,Siljkovic, and M., Milanovic (2015). Long-term impact of foreign direct investment on reduction of 
unemployment: panel data analysis of the Western Balkans countries.Journal of Applied Economics and Business Research, 5 (2), 112-129.

ManpowerGroup (2012).How policymakers can boost youth employment, Manpower-Group, Milwaukee. Retrieved from<https://youtheconomicopportunities.org/resource/2026/ho w-policymakers-can-boost-youth-employment> (accessed July 22, 2019).

Matthew, O.H. and A. A., Johnson (2014). Impact of Foreign Direct Investment on Employment Generation in Nigeria: A Statistical Investigation. IOSR Journal of Business and Management Ver. II, 16(3): 44-56. Retrieved from<https://pdfs.semanticscholar.org/711d/e3cb2dce5a1362d3 c292674ec23011b48bba.pdf $>$ (accessed June 3, 2019).

Mayom, D. A. (2015). The Impact of Foreign Direct Investment on Labor Market Measures: Evidence from Sub-Saharan Africa. Master's Theses. 144.Retrieved from $<$ https://repository.usfca.edu/thes/144> (accessed May 10, 2019). Mucuk, M. and M. T., Demirsel (2013). The effect of foreign direct investments on unemployment: Evidence from panel data for seven developing countries. Journal of Business, Economics \& Finance, 2(3), 53-66.

Palat, M., (2011).The Impact of Foreign Direct Investment on Unemployment in Japan.ActaUniversitatisAgriculturaeetSilviculturaeMendelianae Brunensis, 14(27), 261- 266.Retrieved from $<$ https://acta.mendelu.cz/media/pdf/actaun_2011059070261 .pdf $>$ (accessed June 20, 2019).

Rizvi, S. Z. A., andM.Nishat (2009).The impact of foreign direct investment on employment opportunities: Panel data analysis empirical evidence from Pakistan, India, and China.The Pakistan Development Review, 48(4), 841-851.

Strat, V.A., A.D.,Alexandru, A., Maria, and P., Vass (2015).FDI and the Unemployment: A Causality Analysis for the Latest EU Members.Procedia Economics and Finance, 23, 635-643. 
UNCTAD (2019). World Investment Report: Annex Tables of United Nations Conference on Trade and Development. Retrieved from $<$ https://unctad.org/en/Pages/DIAE/World\%20Investment\%20R eport/ Annex-Tables.aspx $>$ (accessed June22, 2019).

Vacaflores, D. E. (2011). Was Latin America Correct in Relying in Foreign DirectInvestmentto Improve Employment Rates?Applied Econometrics and International Development, 11(2), $101-122$.

WDI (2019).World Development Indicators of the World Bank. Retrieved from $<$ https://data.worldbank.org/indicator $>$ (accessed July 26, 2019).

Zdravkovic, A., M.,Dukic, and A.Bradic-Martinovic. (2017). Impact of FDI on Unemployment in Transition Countries: Panel Cointegration Approach.Industrija, 45 (1).

Zeb, N., F., Qiang, and M. S., Sharif.(2014). Foreign Direct Investment and Unemployment Reduction inPakistan.International Journal of Economics and Research, 5(i2), 10-17. 
